\title{
ATHLETIC LOOKING SALES PERSONNEL: DO MEN BUY MORE FROM MEN?
}

\section{ATLETSKI IZGLED PRODAJNOG OSOBLJA: KUPUJU LI MUŠKARCI VIŠE OD MUŠKARCA?}

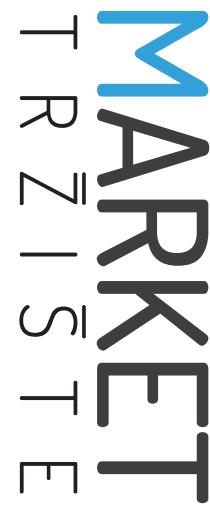

\author{
Market-Tržište \\ Vol. 32, No. 2, 2020, pp. 205-220 \\ UDK 616-007.71:658.8-051.1:658.89-051.1:339.166.82(540) \\ DOl http://dx.doi.org/10.22598/mt/2020.32.2.205 \\ Preliminary communication
}

\section{Raju Rosha ${ }^{a}$, Navdeep Kaur ${ }^{b}$ \\ a Department of Commerce and Management, Tara Vivek College Gajjanmajra, Punjab, INDIA, e-mail: raju.rosha@gmail.com \\ ${ }^{\mathrm{b}}$ Department of Business Administration, Guru Nanak Dev Engineering College (GNDEC), Punjab, INDIA}

\begin{abstract}
Purpose - This empirical study explores the influence of physical prominence of the sales personnel on the purchase behavior of male customers at health supplement and nutraceuticals retail stores. The researchers carried out a first-hand study to investigate the impact of advertisements featuring models "with six-pack abs holding dietary supplement boxes" on customer purchases.
\end{abstract}

Design/methodology/approach - The experimental research method with the observational technique of data collection was employed to study how subjects respond to various stimuli. The data collected through this technique was analyzed by using IBM SPSS 21 . The data was collected by applying the area sampling technique at 12 dietary supplements retail stores in different cities and villages in India from 1 November 2019 to 15 January 2020. The sample consisted of 24 male employees of dietary supplement retail stores and 40 male customers who purchased dietary supplements.

Findings - This research study empirically explores the positive influence of physical prominence (salesman with six-pack abs working at health supplement and nutraceuticals retail stores) on male customer purchase behavior. Its findings support the fact that there is a statistically significant difference between preference levels of customers in the presence and in the absence of advertisements showing models "with six-pack abs holding dietary supplement boxes".

\section{Sažetak}

Svrha - Rad empirijski istražuje utjecaj tjelesnog isticanja (prodajnog osoblja s vidljivim trbušnim mišićima - pločicama zaposlenih u prodavaonicama dodataka prehrani i nutraceutike) na ponašanje muškaraca kao potrošača. Provedeno je istraživanje iz prve ruke kako bi se istražio utjecaj modela korištenih u oglašavanju "koji su imali vidljive trbušne mišiće - pločice i držali kutije $s$ dodacima prehrani" na kupovinu kupaca.

Metodološki pristup - Kako bi se istražilo na koji način ispitanici reagiraju na različite podražaje, u prikupljanju podataka korištena je eksperimentalna metoda istraživanja s tehnikama promatranja. Podaci su analizirani pomoću IBM SPSS 21, a prikupljeni su primjenom tehnike zonskog uzorkovanja u 12 maloprodajnih prodavaonica dodataka prehrani iz različitih gradova i sela u Indiji od 1. studenog 2019. do 15. siječnja 2020. Uzorak se sastojao od 24 muška zaposlenika maloprodajnih prodavaonica dodataka prehrani i 40 muških kupaca koji su kupili te dodatke.

Rezultati - Istraživanje empirijski otkriva pozitivan utjecaj tjelesnog isticanja (prodavača s vidljivim trbušnim mišićima - pločicama koji rade u prodavaonicama dodataka prehrani i nutraceutike) na ponašanje muških kupaca i podržavaju činjenicu da postoji statistički značajna razlika u oglašavanju između razine preferencija kupaca ovisno o prisutnosti i odsutnosti modela "s trbušnim mišićima koji drže kutije s dodacima prehrani". 
Limitation - As the research area was restricted to India only, a larger sample may provide clearer data for an assessment. There may be other variables to be considered in further empirical research studies because the role of a significant influence of other factors cannot be ruled out.

Originality/value - To the best of the authors' knowledge, there has been no research to date highlighting such customer behavior in India. This makes the present paper novel and useful for the scientific community working in this research field. Previous research studies have affirmed the impact of body shape of athletic looking female sales personnel on purchase patterns, but very little is known about the male-to-male sales interactions.

Keywords - athletic looks, sales personnel, health supplement stores, male customers, spending patterns
Ograničenja - Područje istraživanja bilo je ograničeno samo na Indiju. Veći bi uzorak možda pružio jasniju sliku procjene. Mogu postojati i druge varijable koje bi trebalo uzeti u obzir u budućim empirijskim istraživanjima jer se ne može isključiti značajan utjecaj drugih čimbenika.

Doprinos - Prema saznanjima autora, ne postoji istraživanje usmjereno na ovakvo ponašanje potrošača u Indiji. Zbog toga je ovaj članak nov i koristan za znanstvenu zajednicu u tom području istraživanja. Prijašnja su istraživanja potvrdila utjecaj oblika tijela i atletskog izgleda ženskog prodajnog osoblja na obrasce potrošnje, dok je malo poznato o interakcijama muškaraca s muškim prodajnim osobljem.

Ključne riječi - atletski izgled, prodajno osoblje, prodavaonice dodataka prehrani, muškarci kao potrošači, obrasci potrošnje 


\section{INTRODUCTION}

Bharat Ganarajya, officially known as India, is the second most populous country in the world and the seventh largest by area size (Ravilochanan \& Devi, 2012). India is going through a demographic transition and, by the end of the year 2021, its population of 15-59 year old people is expected to account for $63 \%$ of the total (Guha, 2013). To reap the benefits of such demographical change, it is very important that the Bharat Ganarajya should have a healthy population. In the recent past, health supplement retail stores in India have been known to recruit athletic looking male sales personnel with six-pack abs (Menon \& Ruzzarim, 2012). However, researchers are still doubtful about whether such recruitment policy for health supplement and nutraceuticals retail stores are more effective in attracting customers into making more purchases (Peighambari, Sattari, Kordestani \& Oghazi, 2016). Many research studies have revealed that persons with muscular bodies show signs of physical prominence and are perceived to be belong to a higher-income social class (Siddiqui, 2016). It is also given that females prefer the presence of sales personnel who has attractive appearance, which may trigger competition in customers as well. Not all homo sapiens can vie with a strong musculature, so they become passionate about purchasing costly products in order to leave a mark on others and to galvanize their wealth and status (Iraki, Fitschen \& Espinar, 2019). To raise the perception of their status in society, customers buy flashy products at a higher financial cost (Fidrmuc \& Paphawasit, 2018). It is postulated that a personal encounter with an athletic looking sales personnel having six-pack abs might stimulate the customers to purchase more conspicuous and expensive products to accomplish their personal health and physical fitness intensions (Choi, Kim \& Pasnak, 2014). Research studies have unveiled the repercussions of attractive and athletic female sales personnel on male customers' purchase behavior (Nowak \& Jasionowski, 2015). Sexual theories suggest that body attractiveness in males reflects psy- chological alterations (Nisbett \& Wilson, 1977). A male customer encountering another athletic looking man will face an aggravated need to compete and incline towards higher price tag products for consumption (Vaitl et al., 2005). Many marketers used such tactics as a competitive advantage to outperform rivals and create entry barriers (Jacobs \& Cohen, 1999). Research study refer to "health supplement and nutraceuticals retail stores" because the retailers are known for using male model employees having six-pack abs at their sales counters and in their advertisements (Han, 2011). Previous research studies has affirmed the impact of body shape of athletic looking female sales personnel on purchase patterns, but very little is known about male-to-male sales interactions (Seeman, 2020). In the second part of this research study, the influence of advertisements showing models "with six-pack abs holding dietary supplement boxes" on customer purchase intensions was tested. From the customer viewpoint, box packaging acts as a source of information regarding the quality and ingredients of the product. Research studies suggest that advertising creates a unique image in the minds of the customers that builds trust and acceptance. Advertisement models "with six-pack abs holding dietary supplement boxes" lure customers to buy the product. This also creates conformity between brand image and customers' conscious self-image.

To address a gap found in the review of literature, the present research study empirically explores the influence of physical prominence (athletic looking male sales personnel working in health supplement and nutraceuticals retail stores) on the purchase behavior of male customers. In this research study, (study i), the influence of male employees having an athletic body on male customers purchase behavior has been examined; in (study ii), the researcher carried out a first-hand study to investigate the impact of advertisements showing models "with six-pack abs holding dietary supplement boxes" on customer purchase. This research study also fills the gap between the influence of advertisement models and consumer purchase 


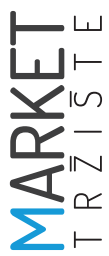

behavior. Conjoint analysis technique was used to provide in-depth knowledge about the relationships among these research variables (Choi et al., 2014). Some of the elements are manipulated and others are incorporated into the experimental realistic settings to test the customer purchase behavior. This research study supported the fact that the feelings of men purchasing high priced items are lifted up after watching male models "with six-pack abs holding dietary supplement boxes". The results of this study show that the presence of athletic looking men either as employees or on advertisement banners motivates the customers to purchase and spend more.

\section{REVIEW OF LITERATURE}

Beauty has fascinated marketers, philosophers, and management for centuries (Srinivasan, Srivastava \& Bhanot, 2014). In fact, ancient Greeks assumed that there is an essential and significant relationship between attractiveness and positive traits (Vercellini, Buggio, Somigliana \& Barbara, 2013). The idea that "beauty helps in marketing" was empirically tested in an influential research design (Anjana, 2018). Even in the contemporary marketing world, marketers apply positive traits of physical appearance to attract customers (Agariya, Johari, Sharma, Chandraul \& Singh, 2012). People with athletic body have been found to enjoy many socio-economic benefits (Anjana, 2018). Many research studies have concluded that physical fitness leads to happiness and life satisfaction (Ahmad \& Lakhan, 2012). Their results suggest that greater physical attractiveness and psychological well-being are significantly correlated, also affecting the life's outcome matrix (Iraki et al., 2019). Health fitness, body attractiveness, occupational success and dominance are the most coveted traits for heterosexual men. In recent years, attractive body has been a great power source of intrigue to marketers (Belknap \& Melton, 2005). Health supplement advertisements are filled with attractive body models boasting their six-pack abs (Johnson, Foster \& McDowel, 2014). As phys- ical manifestations are significant to customers, body appearance is found to be an eye-catching element of an integrated promotional mix (Tibebe, 2018). It has been asserted that athletic looking sales personnel may increase the customer's willingness to buy. To address this, the current research investigates and formulates the first hypothesis to be tested, namely, whether the purchase behavior of male customers has a significant relationship with the athletic looking employees of health supplement and nutraceuticals retail stores.

People also rely on outer appearance, such as size and shape, as content of social media profiles that will form relationships and attract likes (Lahm, 2015). The promotion of healthy body standards in advertisements has been found to lead to healthy eating habits and sound mental health of customers (Bilal, 2013). Body standards and social factors play a substantial role in the establishment of healthy benchmarks regarding physical attractiveness among male customers (Anderson, John, Keltner \& Kring, 2001). People perceived to be attractive improve their potential for better education, higher-salaried jobs and better consumption patterns (Elliot \& Niesta, 2008). Studies assert that physically attractive sales personnel achieve higher customer integration which, in turn, helps support their sales targets while also having a long-lasting effect on customers in terms of building sound customer relationships (Feingold, 1988). Front desk officer's beauty has a well-proven impact on marketing and sales efforts (Khan et al., 2017). Ethnographic research data further revealed that physically attractive sales personnel could prompt more socializing activities with customers to enhance the sales pinch (Wood, Huang, Wood \& Murray, 2014). In addition to evoking a higher spending power, men with physically attractive feature like stature, six-pack abs, and strong biceps have a larger number of intimate comrades and more success (Shahani-Denning, 2000). Muscularity and physical prominence are anatomical beacons of male inherited fitness (Abel, Croysdale \& Stiles, 2009). Physical dominance of men is sexually appealing to the 
opposite sex and intimidating to the same sex (Jordahl, Berggren \& Jordahl, 2006). According to the results of cross sectional multidisciplinary, hypothetically proved, studies using mixed research design techniques, service quality as perceived by customers is enhanced by physically attractive, athletic looking sales personnel; and the underlying mental imaginary during the purchasing time span is complex and often internally inconsistent (Lee, Chen, Yu \& Tsui, 2012).

Related literature establishes the relationship between the male customer purchases and athletic looking employees of health supplement and nutraceuticals retail stores. Previous research studies were focused on the consequences of allurement, especially feminine facial expressions, body countenance, and related stereotypes on purchase behavior (Fardouly, 2018). However, customers can attain social status and acceptance to high-end reference groups by impressing others through reputation rather than being physically more powerful or influential (Fidrmuc \& Paphawasit, 2018). Thus, to some extent, customer will convey their fitness goals to potential companions and vie with rivals (Wade, 2010). For example, there are more chances that male customers will display physical achievement, as a method of trumping competition and approaching the opposite gender, than female customers (Bernon \& Johnson, 2018). Price value combined with product noticeability is the most prominent cue in making conjectures about the status of customers (Guha, 2013). Some male customers are also more prone than others to noticeable and branded product consumption patterns as a method to convey their social standing (Grant, 2013). This kind of customer expenditure rivalry can be more expected during competition or interaction with other customers and, consequently, results in increased market exploration for better products, famous brands, and services that indicate glory and prosperity to others in the society (Babalis, Ntintakis, Chaidas \& Makris, 2013). Only male customers with sufficiently large amount of financial resources can afford to display high priced and branded products in an extravagant, unfettered prodigal way; thus, such cues may only be used by a limited segment of customers (Shahani-Denning, 2000).

Consequently, societal status symbols of high cost consumption is a valuable intra-sexual antagonism approach within and between customers, signaling what might be too luxurious for rival customers to imitate (Jordahl et al., 2006). Literature research has looked extensively into the spending patterns of male customers. However, little is known about the influence of physically dominant men on male purchasing behavior. To address this gap in the literature, the current research investigates and formulates the second hypothesis, whether the male customer spends more in the proximity of athletic looking employees of health supplement and nutraceuticals retail stores. Even though this type of homogeneous customer competition usually occurs in the presence of the opposite sex, such aggressive social exhibition can also take place in their absence (Fardouly, 2018).

Male customers occasionally like to do "flash" even in the absence of women to make an impression as they seek to build up their status and place in the male hierarchy in order to gain strength, respect, and social standing (Elliot \& Niesta, 2008). How, then, might physical prominence influence male customers purchase behavior? It has been asserted that sales personnel with six-pack abs and strong biceps may be viewed with respect, which, in turn, could increase sales and customers' willingness to purchase from such healthy and fit sales representatives. This is statistically significant in the case of males of tall stature and with athletic body, as a physical symbol of fitness and higher status, having a high positive correlation with income and occupations (Ha \& Maaninen-Olsson, 2014).

In addition, recruitment strategies of male sales personnel have been commonly influenced by the stature of job seekers (Szymanski, Moffitt \& Carr, 2011). It is also assumed that such salespeo-

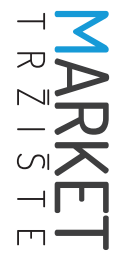




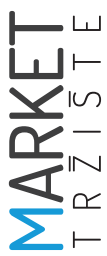

ple ought to have a distinct influence on male consumers' purchasing behavior because their manly appearance is likely to activate intra-sexual rivalry among customers (Wood et al., 2014). This proposed concept heightens the compelling force of same gender rivalry, which transfigures the sales personnel into competitors and results in a higher tendency by male buyers to buy high status and branded products (Jordahl et al., 2006). Research studies further posit that less physically dominant male customer (shorter in stature or having a weak body) will feel a stronger internal drive to compete with physically dominant male sales personnel and their willingness to do so by purchasing branded products and services that show off their financial supremacy (Fardouly, 2018).

The literature related to an established relationship between the advertisements showing models "with six-pack abs holding dietary supplement boxes" and customer purchasing intensions has also been examined. In fact, a study by Otterbring, Ringler, and Sirianni (2018) reveals that customers of short stature are more inclined to compensatory behavior to compensate. Put differently, men who are less dominant in bodily terms are incapable of competing through their own physique (Belknap \& Melton, 2005). We believe that they are more likely to compete by other means, such as spending to signal their social status (i.e., consumption of luxury products with a high price tag or advertisement prints on packing). The right box packaging can help a brand achieve the maximum slice of the market and a distinctive spot in the minds of the customers (Downey, Roberts \& Stough, 2011). Packaging has the best reach compared to other forms of advertising, and can set a company brand aside from its rivals (Vijaya, Niharika \& Lahari, 2017). It promotes and positively reinforces the customer purchase decision making at the point of purchase at health supplement and nutraceuticals retail stores (Otterbring et al., 2018). Packaging displaying models "with six-pack abs holding dietary supplement boxes" helps the product expand into new target markets while also helping marketers overcome high-cost barriers (Bmi, 2004). Packaging can even influence brand choice, especially in the case of health supplements (Alvani, Mehrshad, Hosseini \& Kimura, 2016).

In India, marketing is becomes more aggressive and product packaging needs to offer even more than just functional benefits and data intelligence to the loyal customers (Babalis et al., 2013). Even though the research studies mentioned have not discussed whether physically dominant male models shown on advertisements could influence male customers differently, we hypothesize that the advertising using male models "with six-pack abs holding dietary supplement boxes" influences customer purchasing intentions. Time pressure and low personal involvement in dietary supplement purchases means that few minutes are spent on looking at product details and information provided on packaging (Siddiqui, 2016). The advertisement models "with six-pack abs holding dietary supplement boxes" not only influence customer purchasing intentions but also convince the customer to accomplish the inner craving for the product. Such advertisements usually keep pace with the demand, so that customers are willing to pay extra for their appearance and their prestige.

\section{RESEARCH METHODOLOGY}

After extensively surveying the literature, the following research framework was developed. To study how subjects respond to various stimuli, the experimental research method with the observational technique of data collection was employed. The data collected through this technique was analyzed by using IBM SPSS 21. The lack of research related to the athletic looking sales personnel (and the very issue of whether men buy more from men in India) made it essential to use primary sources of data collection to test the hypotheses and to achieve the required research objectives of this study. 
TABLE 1: Research variables

\begin{tabular}{|c|c|c|c|}
\hline Study & Participants & Independent variable & Dependent variable \\
\hline Study 1 & 24 employees & dominant employee & spending \\
\hline Study 2 & 40 customers & $\begin{array}{c}\text { male model (with six-pack abs } \\
\text { holding dietary supplement } \\
\text { boxes) }\end{array}$ & $\begin{array}{c}\text { ranking appeal } \\
\text { preference level }\end{array}$ \\
\hline
\end{tabular}

The data was collected by applying the area sampling technique at 12 dietary supplements retail stores in different cities and villages in the period between 1 November 2019 and 15 January 2020. The sample consisted of 24 male employees of dietary supplements retail stores and 40 male customers who purchased dietary supplements. In research study 1, a total of 12 dietary supplements sold at the retail stores were selected at random and split into two halves of 6 retail stores each, forming an experimental group $=E(R)$, and the other 6 forming a control group $=C(R)$. The customers coming to the stores $E(R)$ were exposed to the male employees having "an athletic body with six-pack abs $=(X)$ " for 7 days. In the second part of research study 1 , a sample of 12 dietary supplements sold at the retail stores was selected at random and split into four among groups: 3 retail stores formed a pre-tested experimental group $=E(R), 3$ retail stores formed an un-pretested experimental group $=U E(R)$, with another 3 retail stores forming a pre-tested control group $=C(R)$ and the last 3 forming an un-pretested control group = UC(R). In research study number 2 , the conjoint analysis technique was used to test preference levels among customers. Accordingly, the hypotheses were:

$H_{\text {: }}$ : The purchasing behavior of male customers has a significant relationship with the employ- ees having an athletic body with six-pack abs at health supplement and nutraceuticals retail stores.

$H_{2}$ : Male customers spend more in the proximity of employees having an athletic body with sixpack abs at health supplement and nutraceuticals retail stores.

$H_{3}$ : The advertisement male models "with sixpack abs holding dietary supplement boxes" influence customer purchasing intentions.

\section{RESULTS AND EXPERIMENTS CONDUCTED}

\subsection{Study 1: Influence of employees having an athletic body with six-pack abs on customer purchases}

The primary objective of this research study was to investigate the influence of employees having an athletic body with six-pack abs on the purchase behavior of male customers. Research focused only on purchasing behavior in the presence or absence of employees of described physical characteristics. To test this hypothesis in a department store, the Solomon four-group experimental design was used (Muchiri, Barchok \& Nephat, 2015).

TABLE 2: Sales results (pre-test \& post-test) averages

\begin{tabular}{|l|c|c|c|}
\hline \multicolumn{1}{|c|}{ Group } & Pre-test (7 days sales) & Treatment & Post-test (7 days sales) \\
\hline Experimental group $=\mathrm{E}(\mathrm{R})$ & USD 91,426 & $X$ & USD 12,920 \\
\hline Control Group $=\mathrm{C}(\mathrm{R})$ & USD 92,813 & & USD 11,785 \\
\hline
\end{tabular}


This is the classical type of experimental research design which has good internal validity (Siddiqui, 2016). The external validity of the research study is limited by employing pre-testing measures. The customers coming to the stores $E(R)$ and $U E(R)$ were exposed to the male employees having "an athletic body with sixpack abs $=(X)^{\prime \prime}$ for 7 days. Four measurements were considered in all. Then, the sales of all the groups were measured to obtain post-test measures (USD 1,920 - USD 1,785 = USD 135). pack abs: absent, present) to compare results of the analysis of variance by using ANOVA, the relative variance between the research variables to test whether the male customers purchase more expensive products in the presence of such dominant employees at health supplement and nutraceuticals retail stores. The interrelatedness impact was statistically significant.

Table 4 indicates that the degree of the correlation coefficient between dominant employees and spending (the amount of money spent on

TABLE 3: Study results according to the Solomon Four-Group design

\begin{tabular}{|l|c|c|c|}
\hline \multicolumn{1}{|c|}{ Group } & Pre-test (7 days sales) & Treatment & $\begin{array}{c}\text { Post-test (7 days } \\
\text { sales) }\end{array}$ \\
\hline Pre-tested exp. group = E (R) & USD 4,5713 & $X$ & USD 6,7400 \\
\hline Pre-tested control group = C (R) & USD 4,6406 & & USD 56,913 \\
\hline Un-pretested exp. group = UE (R) & & $X$ & USD 57,520 \\
\hline Un-pretested control group = UC (R) & & & USD 51,272 \\
\hline
\end{tabular}

The customers in the experimental group retail stores were greeted by male employees having an athletic body with six-pack abs and wearing net t-shirts. Research data was collected at weekends only in order to control the effect of all extraneous variables. The purpose of the research study was not discussed with the customers. The researcher took snapshots of the items purchased by the customers and collected total sales data from the register at the end of the day. This was done for 2 (retail stores: village, city) $\times$ 2 (employees having an athletic body with six- consumption goods at the retail store) by customers is 0.212 . Only $73.2 \%$ of the total variation in customer spending is explained by the dominant employee. The adjusted $R$ squared was 0.687 , with the standard error of the estimation at 4.02462 .

According to results in Table 5 below, or the ANOVA table, the linear regression model predicts the spending pattern variables significantly well. The sum of squares was 49.311 for regression, 1052.912 for the residual factor. The $F$ value of 46.740 was statistically significant.

TABLE 4: Model summary (dominant employee - customer spending)

\begin{tabular}{|c|c|c|c|c|}
\hline Model & R & R squared & Adjusted R squared & Std. error of the estimate \\
\hline Linear regression & $.852^{\mathrm{a}}$ & .732 & .687 & 4.02462 \\
\hline
\end{tabular}

a. Predictors: (constant), dominant employee

TABLE 5: ANOVA (dominant employee - customer spending)

\begin{tabular}{|l|c|c|c|c|c|}
\hline \multicolumn{1}{|c|}{ Model } & Sum of squares & df & Mean square & F & Sig. \\
\hline Regression & 49.311 & 1 & 49.311 & 46.740 & $.000^{b}$ \\
\hline Residual & 1052.912 & 998 & 1.055 & & \\
\hline Total & 1102.223 & 999 & & & \\
\hline
\end{tabular}

a. Dependent variable: spending of customers

b. Predictors: (constant), dominant employee 
The $p$ value in Table 5 above is statistically significant. Thus, the given regression model, which was run on SPSS software, significantly estimates the outcome variable. ticals retail stores who have an athletic body with six-pack abs.

Table 7 shows the mean value of sales in the experimental group $=E(R)$ to be the highest at

TABLE 6: Coefficients table (dominant employee - spending of customers)

\begin{tabular}{|c|c|c|c|c|c|c|}
\hline \multicolumn{2}{|c|}{\multirow{2}{*}{ Model }} & \multicolumn{2}{|c|}{$\begin{array}{c}\text { Unstandardized } \\
\text { coefficients }\end{array}$} & $\begin{array}{c}\text { Standardized } \\
\text { coefficients }\end{array}$ & \multirow{2}{*}{ t } & \multirow{2}{*}{ Sig. } \\
\cline { 3 - 7 } & B & Std. error & Beta & & \\
\hline \multirow{2}{*}{ Variables } & (Constant) & 3.267 & .158 & & 20.694 & .000 \\
\cline { 2 - 7 } & dominant employee & .228 & .033 & .212 & 6.837 & .000 \\
\hline
\end{tabular}

a. Dependent variable: customer spending

The results in Table 6 provide sufficient data to predict the spending patterns by customers in the presence of a dominant employee. Looking at the "Sig." column, for the hypothetical data, the unstandardized path coefficient was 0.228, $\mathrm{t}(998)=6.837$, and $p<.05$ was statistically significant. Thus, Hypothesis $H_{1}$ was accepted. It also revealed the significance of dominant employees. Hence, the purchase behavior of male customers has a significant relationship with the employees of health supplement and nutraceu-
26.100, followed by 23.6222 in the un-pretested control group $=U C(R)$. A higher deviation in experimental and controlled group readings is treated as favorable. In the presence of employees having an athletic body with six-pack abs, male customers purchased more in dollar terms (26.1000-23.6222) in the proximity of other male employees of health supplement and nutraceuticals retail stores with such bodily characteristics.

TABLE 7: Test statistics of controlled and uncontrolled groups (sales in USD)

\begin{tabular}{|c|c|c|c|c|c|c|c|c|}
\hline & \multirow{2}{*}{$\mathbf{N}$} & \multirow{2}{*}{$\begin{array}{c}\text { Mean } \\
\text { of retail } \\
\text { store } \\
\text { sales }\end{array}$} & \multirow{2}{*}{$\begin{array}{c}\text { Std. } \\
\text { deviation }\end{array}$} & \multirow{2}{*}{ Std. error } & \multicolumn{2}{|c|}{$\begin{array}{l}95 \% \text { Confidence } \\
\text { interval for mean }\end{array}$} & \multirow{2}{*}{ Minimum } & \multirow{2}{*}{ Maximum } \\
\hline & & & & & $\begin{array}{l}\text { Lower } \\
\text { bound }\end{array}$ & $\begin{array}{l}\text { Upper } \\
\text { bound }\end{array}$ & & \\
\hline$E(R)$ & 3 & 26.1000 & 2.03666 & 0.86268 & 24.0087 & 28.2701 & 21.00 & 32.00 \\
\hline$C(R)$ & 3 & 22.5000 & 2.20545 & 0.03452 & 20.1235 & 24.8543 & 17.00 & 28.00 \\
\hline UE (R) & 3 & 22.3000 & 2.12755 & 0.01304 & 20.0721 & 24.6057 & 17.00 & 28.00 \\
\hline$U C(R)$ & 3 & 23.6222 & 2.45151 & 0.54015 & 22.3023 & 25.0522 & 17.00 & 28.00 \\
\hline Total & 12 & 23.6305 & 2.20529 & 0.36259 & 21.6266 & 25.6955 & 17.00 & 32.00 \\
\hline
\end{tabular}

TABLE 8: ANOVA analysis

\begin{tabular}{|l|c|c|c|c|c|}
\hline & Sum of squares & df & Mean square & F & Sig. \\
\hline Between groups & 90.356 & 4 & 44.622 & 3.356 & 0.11 \\
Within groups & 165.300 & 7 & 9.126 & & \\
Total & 255.656 & 11 & & & \\
\hline
\end{tabular}


In this part of the research study, an attempt has been made to uncover the interlinkages between test variables in village and city settings. The ANOVA model was found to be statistically significant $(F(1,12)=3.356, p<.05$, $\mathrm{df} .=11)$ between and within groups. Thus, Hypothesis $\mathrm{H}_{2}$ was accepted. The study observed that the male customer spends more in the proximity of other male employees of health supplement and nutraceuticals retail stores having an athletic body with six-pack abs.

The upper bounds and maximum limit points of average spending in dollar terms are demonstrated by topmost lines in Graph 1 (a, b).

\section{GRAPH 1 (a, b): Upper and Lower Limits}
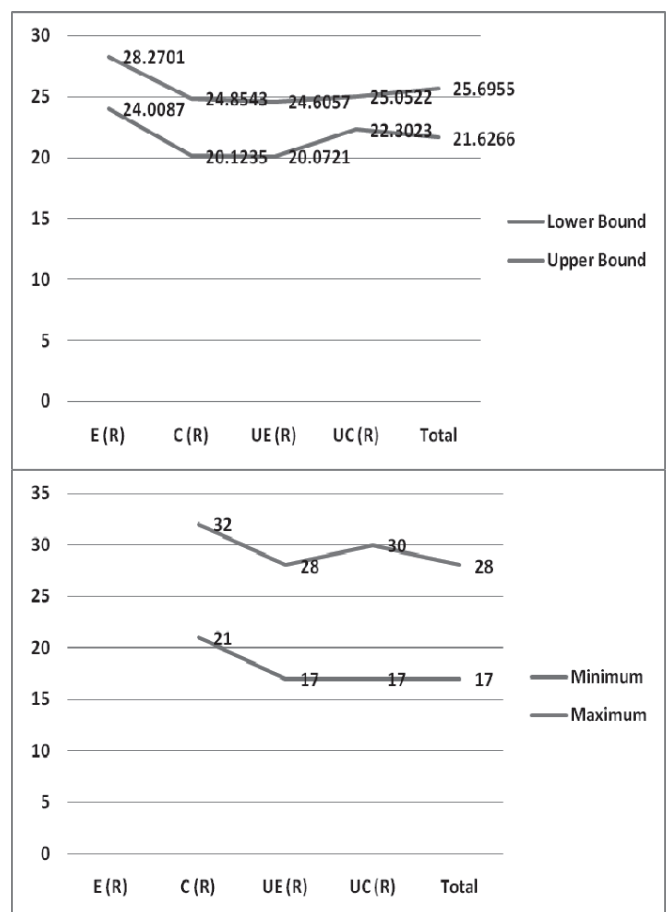

Overall, research study 1 demonstrated that male customers purchased more products in the presence of male employees having an athletic body with six-pack abs. Such are beneficial to the marketers. Study 1 was conducted in live experimental and control settings. The researcher could not fully control the extraneous variables that are likely to shape outcomes. Experimental group settings meant that there was no control over the customers and whether they shop alone, with a partner, family or friends (Grant, 2013).

\subsection{Study 2 : Influence of box packaging design features on customer purchase}

The researcher conducted an empirical research study to investigate the influence of advertisements showing male models "with six-pack abs holding dietary supplement boxes" on customer purchases. In study 2, the conjoint analysis technique was used to test buying intentions of the customers (Green \& Srinivasan, 1978), who were presented with images of the models (present, absent) with six-pack abs holding dietary supplement boxes. That graphical design on the supplement box and its shape acted as a stimulus point for the customers. All other aspects of the supplement box packaging were manipulated for the sake of experimental research design.

A small group of 40 customers participated in the qualitative research study (100\% male, $M_{\text {age }}=24.5$ ) using an online picture and questionnaire on an 8- inch tablet. In the first setup, customers were requested to rank three different packs. In the second setup, they were asked to choose one of the three boxes they would prefer to buy even in the case of a slight increase in price (hypothetical question). Two factors (model present, absent) represented two possibilities (unnoticeable, noticeable). This resulted in a $2 \times 2$ conjoint design analysis with four outcome profiles, as shown in Image 1.

In a completely experimental setup, the researcher was interested in investigating empirically the ability of male customers to be influenced by the image of male models "with six-pack abs holding dietary supplement boxes" while purchasing. In experimental settings, customers completed an itemized social interaction scale (McCain, 1974; a = .69). 
IMAGE 1: Models holding dietary supplement boxes 1, 2 \& 3
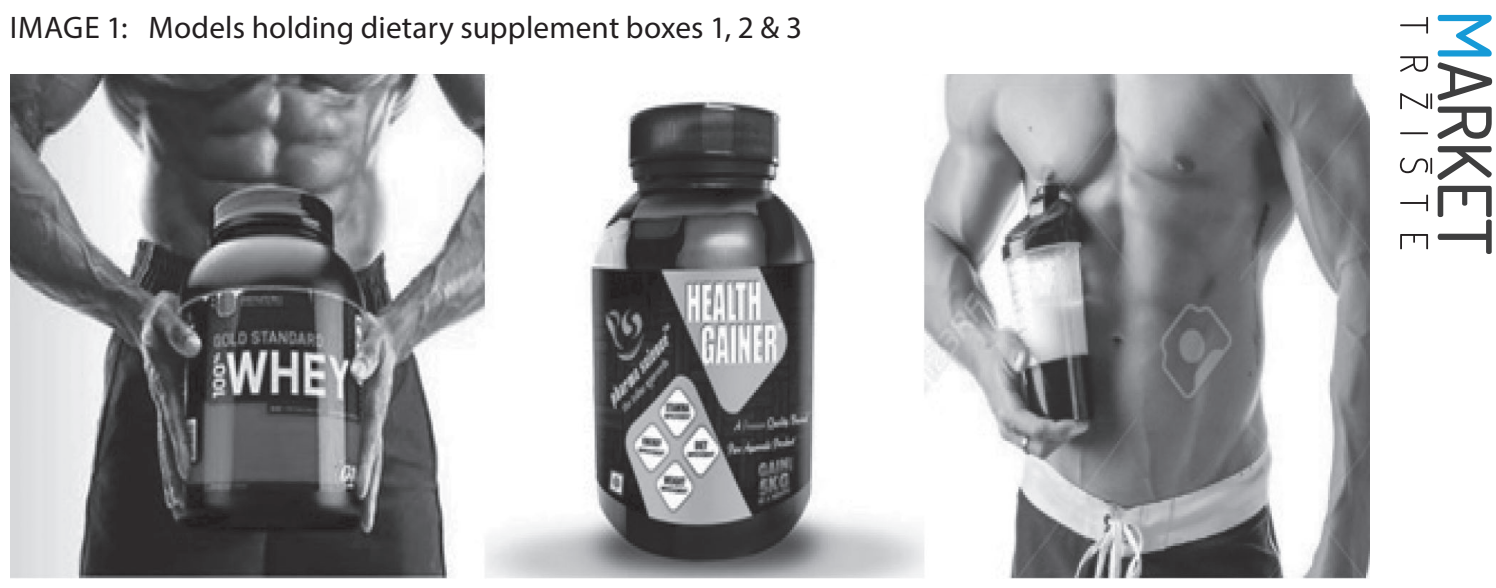

TABLE 9: Utility scores with ranking appeal and preference level measures

\begin{tabular}{|l|l|c|c|c|c|c|c|}
\hline & & \multicolumn{3}{|c|}{ Ranking appeal } & \multicolumn{3}{c|}{ Preference level } \\
\hline Factor & Level & $\begin{array}{c}\text { Utility } \\
\text { estimate }\end{array}$ & $\begin{array}{c}\text { Std. } \\
\text { error }\end{array}$ & $\begin{array}{c}\text { Importance } \\
\text { values }\end{array}$ & $\begin{array}{c}\text { Utility } \\
\text { estimate }\end{array}$ & Std. error & $\begin{array}{c}\text { Importance } \\
\text { values }\end{array}$ \\
\hline Model & Absent & 1.221 & 0.121 & 28.859 & 2.588 & 0.450 & 34.634 \\
\hline & Present & 2.443 & 0.364 & 31.428 & 3.094 & 0.499 & 39.911 \\
\hline Correlation & Value & \multicolumn{2}{|c|}{ Sig. } & Value & \multicolumn{2}{c|}{ Sig. } \\
\hline Pearson's R & 0.227 & \multicolumn{2}{|c|}{0.001} & 0.280 & 0.007 \\
\hline Kendall's tau & 0.143 & & 0.026 & 0.117 & 0.004 \\
\hline
\end{tabular}

According to Table 9, the outcome matrix clearly supports the subject matter of our research study, specifically, there is a statistically significant difference between preference levels of customers in the presence and in the absence of advertisement models "with six-pack abs holding dietary supplement boxes." The experimental conditions in the presence of the model have the highest utility for the ranking appeal (2.443) and preference level (3.094), so Hypothesis $\mathrm{H}_{3}$ was accepted. Hence, the existence of the influence of advertisement models "with six-pack abs holding dietary supplement boxes" on customer purchasing intentions were proven.

\section{DISCUSSION}

This research study found that physical dominance influences customer behavior in terms of product type consumption when it comes to the products indicating social standing through exorbitant prices or packaging with visual bodily image. However, this need not necessarily be the case with other products categories. In both research setups, i.e. village and city, male consumers were likely to buy costly products at health supplement and nutraceuticals retail stores in the presence of employees having an athletic body with six-pack abs. Intra-sexual competition with sales personnel having such athletic body leads to more consumption of status signaling products and services (Johnson et al., 2014). This study also bridges a gap in the research of the relationship between advertisement models "with six-pack abs holding dietary supplement boxes" and customer purchase behavior. The final purchase decision making by male customers is mostly influenced by the outer box graphics of body builder pictures (Derdenger, Li \& Srinivasan, 2018). The images 


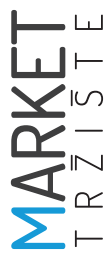

showing advertisement models "with six-pack abs holding dietary supplement boxes" act as cues that spark higher buying intention within male customers, in addition to the utility function of the box.

\section{CONCEPTUAL IMPLICATIONS}

Adding to the emergent literature of scalable customer research studies, the main theoretical implications of this research work is the finding that physically dominant sales personnel has a substantial impact on the buying behavior of male customers. Whereas prior research literature usually paid attention to the effect of attractive female sales personnel on high cost spending of male customers, signaling social status (Lee et al., 2012), the emphasis in the this research study is on the influence of physical prominence on male customers purchase behavior. The charisma of physically imposing sales personnel of health supplement and nutraceuticals retail stores seems to influence the way in which their male customers shopped. Images of physically stronger models with sixpack abs holding dietary supplement boxes caused greater preference among customers for branded health supplements and nutraceuticals products that show off their financial supremacy. At the comprehensive level, our findings recall those of previous research focusing on male customers whose own self-opinions have been questioned (Agariya et al., 2012). Customers are highly motivated to purchase products that reinforce their self-image, so relational value messages about products are very important (Kim \& Kumar, 2018).

\section{MANAGERIAL IMPLICATIONS}

The research team monitored the purchases customers made at health supplement and nutraceuticals products retail stores in an Indian city and village during seven weekdays.
When athletic looking male sales personnel stood at the front desk, male customers spent significantly more dollars than usual. Physically dominant sales personnel can boost the consumption of status-signaling products. When male customers see athletic looking male sales personnel, a rivalry instinct may be activated, so they respond by opening their own wallets and buying. At any rate, it must be noted that the outcome of physically dominant sales personnel in both of our controlled and uncontrolled research studies was positively significant, demonstrating a general increase in sales and consumption of status-signaling products and services as a function of male customer bodily dominance. The researchers suggest that sales-driven retail stores could take advantage of our research findings by recruiting athletic male sales personnel to manage the purchase behavior of male customers shopping for prominent luxury goods, such as cars, elite class watches, clothes, and platinum jewelry (Khan et al., 2017).

In addition, our general research findings suggest that premium designer brands, such as Burberry, Gucci, Armani, Hugo Boss, Louis Vuitton, Hermes, and Jimmy Choo, could reap benefits of recruiting physically dominated sales personnel for their haberdasher segments. And, as shown in our follow-up control group research study, it is important for box packaging designers to maintain congruity with product ingredients, as the outer picture of the box label seems to have a significant influence on the overall utility. The designed images of physically strong models with six-pack abs holding dietary supplement boxes were found to have greater utility as such health supplement and nutraceuticals boxes were the ones male customers mainly picked up for purchasing (Guha, 2013). E-commerce platform marketers might put an emphasis on high-priority interactions with customers during the current coronavirus pandemics. The most valuable screen real estate may use advertisements of male models "with six-pack abs holding dietary supplement boxes" to grab attention of stay-home customers in lockdown environments. This strategy may fur- 
ther extend to advertisements, all type of media commercials, in-store and outdoor displays. It could enhance male customers' motivation to consume more high-end products. Thus, this evolutionary research study has wide ranging implications for not just retail recruitments but also for advertising agencies and marketing strategists.

\section{FUTURE RESEARCH}

Past research studies have looked broadly at the influence of appealing women on buying behavior of male customers in India. Some parameters with a different setup and different analysis techniques in the first part one of the present research paper were taken from the paper titled Impact of Physical Dominance on Male Customers' Status-Signaling Consumption (Otterbring et al., 2018). That study was conducted to explore an outcome with changed social economic preferences of the Indian consumer having a different culture and geographical location. However, less is known about the influence of physically dominant men on other men's behavior. The present research study provides final proof that male physical superiority of sales personnel affects the buying behavior of other male customers. Most male customers usually describe their companionship through social standing while female customers tend to be involved in an act that boosts their beauty and bodily health. Consequently, a suggestion for upcoming research study is to investigate in detail whether physically dominant sales personnel might be able to get female consumers to pay more for products relating to beauty and health than those enhancing their personal prosperity. Future research studies could explore whether females would be more willing to pay for luxurious goods and services in the presence of female sales personnel. It has already been statistically confirmed that exposure to physically alluring female increases men's readiness to spend exorbitantly on products relating to social standing (Kumar, John \& Senith, 2014). However, an important topic for subsequent research studies could be the kind of sales personnel (e.g., physically appealing female sales personnel or physically powerful and influential male sales personnel) that has a considerable influence on buyers' consumption of products serving as status symbols, thus exploring inter-sexual attraction between genders vs. intra-sexual competition among counterparts. Although more research is required to gain a holistic view of the "impact of employees having an athletic body with six-pack abs on the purchase behavior of male customers", this research study plays a significant role in revealing how men's physical influence affects other men's buying behavior.

\section{LIMITATIONS OF THE RESEARCH}

Undoubtedly, the present research study makes an important contribution to the marketing strategies in the retail sector, which may use its findings for specific decision making. But it also has some limitations: First, the research area for the study was restricted to India only. As sample size was limited to 24 male employees of dietary supplements retail stores and 40 male customers who purchase the dietary supplements, a larger sample may provide clearer data for an assessment. Second, only three dependent variables i.e. spending, ranking appeal, and preference level were used in this research study, but there may be other variables to consider in further empirical research studies because the role of other factors having a significant influence cannot be ruled out.

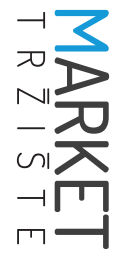




\section{References}

1. Abel, M. H., Croysdale, A., \& Stiles, S. (2009). The Influence of Physical Attractiveness on Promotion Recommendations in Male and Female Applicants. American Journal Of Psychological Research, 5(1), 97-110.

2. Agariya, A. K., Johari, A., Sharma, H. K., Chandraul, U. N. S., \& Singh, D. (2012). The Role of Packaging in Brand Communication. International Journal of Scientific \& Engineering Research, 3(2), 1-13.

3. Ahmad, N., \& Lakhan, A. (2012). Effect of Product Packaging in Consumer Buying Decision Research Statement: Literature Review. Journal of Business Strategies, 6(2), 1-10.

4. Alvani, S. R., Mehrshad, S., Hosseini, P., \& Kimura, L. W. (2016). Relationship between Body Weight and Self-Esteem : A Study of Young Men and Women in Iran. Journal of Obesity and Overweight, 2(2), $1-8$.

5. Anderson, C., John, O. P., Keltner, D., \& Kring, A. M. (2001). Who Attains Social Status? Effects of Personality and Physical Attractiveness in Social Groups. Personality Processes And Individual Differences, 81(1), 116-132.

6. Anjana, S. S. (2018). A study on factors influencing cosmetic buying behavior of consumers. International Journal of Pure and Applied Mathematics, 118(9), 453-459.

7. Babalis, A., Ntintakis, I., Chaidas, D., \& Makris, A. (2013). Design and Development of Innovative Packaging for Agricultural Products. Procedia Technology, 8, 575-579.

8. Belknap, J., \& Melton, H. (2005). Are Heterosexual Men Also Victims of Intimate Partner Abuse?. National Electronic Network on Violence Against Women, 3, 1-12.

9. Bernon, M., \& Johnson, M. (2018). Product recalls: The effects of industry, recall strategy and hazard, on shareholder wealth. International Journal of Business Science and Applied Management, 13(1), 1-14.

10. Bilal, M. (2013). Integrated Marketing Communication: A Review. Interdisciplinary Journal Of Contemporary Research, 5(5), 124-133.

11. Bmi, T. (2004). Appropriate body-mass index for Asian populations and its implications for policy and intervention strategies. Public Health, 363(1), 157-163.

12. Choi, E., Kim, J., \& Pasnak, R. (2014). Physical Attributes and Physical Attractiveness. International Journal of Humanities Social Sciences and Education, 1(11), 35-37.

13. Derdenger, T. P., Li, H. U. I., \& Srinivasan, K. (2018). Firms ' Strategic Leverage of Unplanned Exposure and Planned Advertising: An Analysis in the Context of Celebrity Endorsements. National Intimate Partner and Sexual Violence Survey, 55(2), 14-34.

14. Downey, L. A., Roberts, J., \& Stough, C. (2011). Workplace Culture Emotional Intelligence and Trust in the Prediction of Workplace Outcomes. International Journal of Business Science and Applied Management, 6(1), 30-40.

15. Elliot, A. J., \& Niesta, D. (2008). Romantic Red: Red Enhances Men's Attraction to Women. Journal of Personality and Social Psychology, 95(5), 1150-1164.

16. Fardouly, J. (2018). Instagram use and young women's body image concerns and self-objectification: Testing mediational pathways. New Media \& Society, 20(1), 1380-1395.

17. Feingold, A. (1988). Matching for Attractiveness in Romantic Partners and Same-Sex Friends: A Meta-Analysis and Theoretical Critique. Psychological Bulletin, 104(2), 226-235.

18. Fidrmuc, J., \& Paphawasit, B. (2018). Beautiful Minds: Physical Attractiveness and Research Productivity in Economics. Media and Technology, 44(3), 710-735.

19. Grant, A. M. (2013). Rethinking the Extraverted Sales Ideal: The Ambivert Advantage. Psychological Science, 24(6), 1024-1030.

20. Green, P. E., \& Srinivasan, V. (1978). Conjoint Analysis in Consumer Research: Issues and Outlook. Journal of Consumer Research, 5, 103-123. 
21. Guha, S. (2013). The changing perception and buying behavior of women consumer in Urban India. IOSR Journal of Business and Management, 11(6), 34-39.

22. Ha, T., \& Maaninen-Olsson, E. (2014). Factors that influence consumer purchasing decisions of Private Label Food Products A case study of ICA Basic. Malardalens Hogskola Eskilstuna Vasteras, 214(3), 80-93.

23. Han, Y. J. (2011). Signaling Status with Luxury Goods: The Role of Brand Prominence. Journal of Marketing, 74(4), 1547-7185.

24. Iraki, J., Fitschen, P., \& Espinar, S. (2019). Nutrition Recommendations for Bodybuilders in the Off -Season: A Narrative Review. Sports, 1(5), 1-19.

25. Jacobs, D., \& Cohen, D. (1999). What is really known about psychological alterations produced by psychiatric drugs?. International Journal Of Risk \& Safety in Medicine, 12(1), 37-47.

26. Johnson, L. L. A., Foster, L. D., Mcdowell, L. J., C., \& Usn, M. C. (2014). Energy Drinks: Review of Performance Benefi ts, Health Concerns, and Use by Military Personnel. Military Medicine, 179, 375-380.

27. Jordahl, H., Berggren, N., \& Jordahl, H. (2006). The Looks of a Winner: Beauty, Gender and Electoral Success. Forschungsinstitut Zur Zukunft Der Arbeit Institute for the Study of Labor, 1, 1-24.

28. Khan, I., Dongping, H., Abdullah, M., Ahmad, Z., Ghauri, T. A., \& Ghazanfar, S. (2017). Men's attitude and motivation toward consumption of grooming products: A comparison of Chinese and $\mathrm{Pa}$ kistani male consumers. Cogent Business \& Management, 29(1), 1-14.

29. Kim, K. H., \& Kumar, V. (2018). The Relative Influence of Economic and Relational Direct Marketing Communications on Buying Behavior in Business-to-Business Markets. American Marketing Association, 40, 48-68.

30. Kumar, H. H., John, S. F., \& Senith, S. (2014). A Study on factors influencing consumer buying behavior in cosmetic Products. International Journal of Scientific and Research Publications, 4(9), 1-6.

31. Lahm, R. J. (2015). The small business promotional mix: Complex choices abound between traditional and social media. Journal of Management and Marketing Research, 18, 1-19.

32. Lee, C., Chen, Y., Yu, T., \& Tsui, P. (2012). Effect of physical attractiveness and customer perceived service quality in the cosmetology industry. African Journal of Business Management, 6(15), 5201-5207.

33. Menon, D., \& Ruzzarim, R. C. (2012). Protein Consumption By Bodybuilding Practitioners Aiming Muscle. Exercise And Sports Medicine Clinic, 18, 1-5.

34. Muchiri, J. M., Barchok, H. K., Nephat, J. K. (2015). Effect Of Computer Assisted Teaching Strategy On Students' Achievement In Agriculture In Secondary Schools In Kenya. Merit Research Journal of Education and Review, 3(8), 269-274.

35. Nisbett, R. E., \& Wilson, T. D. (1977). The Halo Effect : Evidence for Unconscious Alteration of Judgments. Journal of Feisonality and Social Psychology, 35(4), 250-256.

36. Nowak, D., \& Jasionowski, A. (2015). Analysis of the Consumption of Caffeinated Energy Drinks among Polish Adolescents. International Journal of Environmental Research and Public Health, 5, 7910-7921.

37. Otterbring, T., Ringler, C., \& Sirianni, N. J. (2018). The Abercrombie \& Fitch Effect: The Impact of Physical Dominance on Male Customers' Status-Signaling Consumption. American Marketing Association, 55, 69-79.

38. Peighambari, K., Sattari, S., Kordestani, A., \& Oghazi, P. (2016). Consumer Behavior Research: A Synthesis of the Recent Literature. SAGE Coonsumer Research, April-June, 1-9.

39. Ravilochanan, P., \& Devi, B. S. (2012). Analysis of Customer Preference in Organized Retail Stores. International Journal of Trade, Economics and Finance, 3(3), 209-212.

40. Seeman, M. V. (2020). Why Are Women Prone to Restless Legs Syndrome?. International Journal of Environmental Research and Public Health, 17, 1-8. 
41. Shahani-Denning, C. (2000). Physical Attractiveness Bias in Hiring: What Is Beautiful Is Good. International Journal of Selection and Assessment, 8(1), 1-17.

42. Siddiqui, S. (2016). Study on Retail Stores' Attributes and Increase in Sales By Influencing Consumers. Journal of Research in Business and Management, 4(4), 24-26.

43. Srinivasan, R., Srivastava, R. K., \& Bhanot, P. S. (2014). Impact of age on purchase behavior of luxury brands. Journal of Research in Business and Management, 2(9), 19-32.

44. Szymanski, D. M., Moffitt, L. B., \& Carr, E. R. (2011). Sexual Objectification of Women: Advances to Theory and Research. Counseling Psychologist, 39(1), 6-38.

45. Tibebe, G. (2018). The Effectiveness of Integrated Marketing Communication for High Involvement Product Purchase Decision: In Case of University of Gondar Employees. Pacific Business Review International, 11(4), 17-29.

46. Vaitl, D., Birbaumer, N., Gruzelier, J., Jamieson, G. A., Kotchoubey, B., Ku, A., \& Weiss, T. (2005). Psychobiology of Altered States of Consciousness. Psychological Bulletin, 131(1), 98-127.

47. Vercellini, P., Buggio, L., Somigliana, E., \& Barbara, G. (2013). Attractiveness of women with rectovaginal endometriosis: a case-control study. Endometriosis, 99(1), 212-218.

48. Vijaya, V., Niharika, D. A., \& Lahari, G. (2017). Impact of Gender on Consumer Purchasing behavior. IOSR Journal of Business and Management, 19(8), 33-36.

49. Wade, T. J. (2010). The Relationships between Symmetry and Attractiveness and Mating Relevant Decisions and Behavior: A Review. Symmetry, 2(1), 1081-1098.

50. Wood, A., Huang, L., Wood, S., \& Murray, F. E. (2014). Investors prefer entrepreneurial ventures pitched by attractive men. Crooss Mark, 4(2), 1-5. 